\section{Moja sprawa: o małżeństwie i prawach seksualnych osób z niepełnosprawnością intelektualną na scenie i na ekranie}

Katarzyna Ojrzyńska
TEKSTY DRUGIE 2020, NR 2, S. 66-85

DOI: $10.18318 /$ td.2020.2.5 | ORCID: 0000-0002-4954-8478
W Republice Irlandii do niedawna obowiązywał ustanowiony w 1993 roku zapis w prawie karnym, zgodnie z którym uprawianie seksu z osobą z niepełnosprawnością intelektualną podlegało wysokiej karze więzienia. Wyjątkiem była sytuacja, kiedy osoby podejmujące współżycie pozostawały w związku małżeńskim. Dopiero dwa lata temu wprowadzono zmiany do budzącego wiele kontrowersji prawa. Ograniczają się one w dużej mierze do ustanowienia kategorii „osoby chronionej" (protected person), która obejmuje następujące grupy: osoby niezdolne do zrozumienia, czym jest seks i jakie mogą być jego przewidywalne konsekwencje, osoby niezdolne do podjęcia świadomej decyzji o tym, czy chcą uprawiać seks, oraz osoby niezdolne do wyrażenia zgody na seks słownie, przy użyciu języka migowego lub w inny sposób ${ }^{1}$. Granice tak zdefiniowanej kategorii mogą nadal wydawać się dość arbitralne

1 Omawiany akt prawny można znaleźć na stronie: http://www.irishstatutebook.ie/eli/2017/act/2/enacted/en/html.

\section{Katarzyna}

Ojrzyńska - dr,

adiunkt, Zakład

Angielskiego Dra-

matu, Teatru i Filmu,

Instytut Anglistyki,

Wydział Filologiczny,

Uniwersytet Łódzki.

Zajmuje się kultu-

rowymi studiami

o niepełnospraw-

ności, współczesną

literaturą i teatrem,

oraz studiami irlandz-

kimi. Jest autorką

książki „Dancing As If

Language No Longer

Existed": Dance in

Contemporary

Irish Drama (2015).

W ostatnich latach

publikowała m.in. w:

"HJEAS,",Brno Studies

in English", ,New

Hibernia Review,",Tek-

stualiach, „,Kulturze

współczesnej” i „Text

Matters." Kontakt: ka-

tarzyna.ojrzynska@

uni.lodz.pl 
i problematyczne. Niewątpliwie jednak w swoim nowym brzmieniu irlandzkie prawo gwarantuje osobom z niepełnosprawnością intelektualną o wiele więcej możliwości samorealizacji na polu seksualnym i uczuciowym niż poprzednie regulacje.

Omawiana zmiana prawna została wprowadzona przede wszystkim dzięki debacie społecznej, którą zapoczątkował film Lena Collina Sanctuary (2016). Obraz Collina - podobnie jak sztuka, na kanwie której powstał i którą irlandzki pisarz Christian O’Reilly stworzył specjalnie dla działającego w Galway Blue Teapot, profesjonalnego teatru osób z niepełnosprawnością intelektualną - był formą protestu. Wyrażał zdecydowany sprzeciw wobec dyskryminacyjnych praktyk i regulacji prawnych obowiązujących w Republice Irlandii w duchu prawa do samostanowienia i niezależnego życia - jednego z najważniejszych postulatów współczesnego aktywizmu osób niepełnosprawnych.

Podobnie jak w polskich tekstach kultury, które omówię w dalszej części artykułu, w Sanctuary wszystkie role osób niepełnosprawnych grają aktorzy $\mathrm{z}$ niepełnosprawnościami. Mamy tutaj zatem do czynienia ze strategią stojącą w sprzeczności z powszechną tendencją do obsadzania w tego rodzaju rolach aktorów sprawnych - tendencją, którą dramatopisarka Kaite O'Reilly nazwała „ukaleczaniem” (cripping up) ${ }^{2}$ na wzór tak zwanego uczerniania (blacking up). Termin ten wskazuje na podobieństwa między dyskryminacją ze względu na rasę i na niewpisywanie się w tak zwaną normę fizyczną lub intelektualną. Uczernianie polegało na tym, że biali aktorzy malowali twarze na czarno, wcielając się w postaci Afroamerykanów, które były najczęściej uosobieniem najgorszych rasistowskich stereotypów. Jak stwierdza O'Reilly,

[...] kwestia odgrywania ról osób z uszkodzeniami fizycznymi i sensorycznymi przez aktorów bez niepełnosprawności jest mocno problematyczna, podobnie jak kwestia malowania twarzy białym aktorom, aby mogli odegrać rolę Otella. Tu nie chodzi o moją polityczną poprawność, ale o odrzucenie tego, co ów przekaz implikuje - że nie ma wystarczająco dobrych czarnoskórych lub niepełnosprawnych aktorów, którzy mogliby

2 Moja propozycja tłumaczenia angielskiego terminu wskazuje na efekt, jaki osiąga się poprzez zastosowanie omawianej strategii. Ukaleczanie, które skutkuje powielaniem i umacnianiem stereotypu "kaleki”, prowadzi do psucia, nieudolnego przedstawiania i zubażania („kaleczenia”) postaci poprzez narzucenie jej pewnej aktorskiej maniery. Alternatywą dla tego tłumaczenia może być na przykład "przekaleczanie" - neologizm nawiązujący do "przebrania się za kalekę". 
odegrać tego rodzaju role, i że sprawni biali aktorzy zawsze będą robić to lepiej. ${ }^{3}$

Jest to szczególnie problematyczne w przypadku mainstreamowego aktorstwa, w którym standardy wyglądu i ekspresji cielesnej wydają się bardzo wyśrubowane i sprawnościocentryczne.

Sanctuary upodmiotawia niepełnosprawnych aktorów, pozwalając im samodzielnie wypowiedzieć się w kwestii przysługujących im praw ${ }^{4}$. Nawiązując do teorii postkolonialnej oraz słynnego artykułu Salmana Rushdiego The empire writes back with a vengeance, który ukazał się w dzienniku „The Times” 3 lipca 1982 roku, takie wypowiedzi polityczne i artystyczne, mające na celu podważenie utartych ableistycznych przekonań i stereotypów, nazywam "odpisywaniem sprawnemu centrum"క. Różnym aspektom i skuteczności tego rodzaju strategii poświęcę dalszą część artykułu, omawiając wybrane teksty polskiej kultury, w których aktorzy z niepełnosprawnością intelektualną odnoszą się do kwestii własnej seksualności i przysługujących im praw. Na swój sposób każdy z tych tekstów stanowi formę protestu - zdecydowanego sprzeciwu wobec utrwalonych przekonań oraz istniejącego porządku społecznego, w którym seksualność osób z niepełnosprawnością intelektualną jest najczęściej uznawana za temat tabu.

Omówione przykłady zaczerpnęłam zarówno z kultury masowej, operującej uproszczonymi, choć nadal pod wieloma względami zaangażowanymi

3 K. O'Reilly "Cripping up is the twenty first century answer to blacking up": Peeling and The 'd' Monologues, blog autorki, 08.11.2011, https://kaiteoreilly.wordpress.com/tag/jenny-sealey/ (08.07.2019). Strategię tę bardziej szczegółowo omawia Kirsty Johnston w tekście Krytyczne ucieleśnienie i problem obsady aktorskiej, przeł. K. Ojrzyńska, w: Odzyskiwanie obecności. Niepełnosprawność w teatrze i performansie, red. E. Godlewska-Byliniak, J. Lipko-Konieczna, Fundacja Teatr 21, Warszawa 2017.

Warto podkreślić w tym miejscu, że aktorzy Blue Teapot uczestniczyli procesie twórczym. Tekst sztuki powstał bowiem na podstawie rozmów, które Christian O’Reilly i reżyserka Petal Pilley przeprowadzili z aktorami.

5 Strategię tę omawiam nieco bardziej szczegółowo w artykule Nabila Shabana dialog z kulturq sprawnq , ",Tekstualia" $2017 \mathrm{nr}$ 4/51, https://tekstualia.pl/files/112f0588/ojrzynska_k-nabila_shabana_dialog_z_kultura_sprawna.pdf (08.07.2019). Z perspektywy współczesnych studiów o niepełnosprawności w podobny sposób nawiązują do Rushdiego m.in. amerykańscy badacze David T. Mitchell i Sharon L. Snyder, którzy w 1995 r. nakręcili film dokumentalny Vital Signs: Crip Culture Talks Back. O odpisywaniu centrum w kontekście niepełnosprawności pisze również Dan Goodley w swojej książce Disability studies: an interdisciplinary introduction, Sage, Los Angeles 2011, s. 163-164. 
politycznie komunikatami, jak i z kultury niepełnosprawnej, która w Polsce w coraz bardziej zdecydowany sposób odchodzi obecnie od koncepcji terapii, tworząc między innymi nową estetykę teatru. Analizowane teksty kultury: wybrane odcinki telenoweli Klan, spektakl Moja sprawa teatru Biuro Rzeczy Osobistych oraz - przede wszystkim - sztuka Klauni warszawskiego Teatru 21, ilustrują przekonanie Jacques'a Rancière'a, że: „Praktyki artystyczne są «sposobami działania», które ingerują w ogólny podział sposobów działania i w ich relacje ze sposobami bycia i formami widzialności"6. Pokazują, że obecna w nich subwersywna estetyka niepełnosprawności ${ }^{7}$ wpisuje się w różnym stopniu w to, co Rancière nazywa egalitarnym „estetycznym reżimem sztuki", czy to z uwagi na rodzaj sztuki (zaangażowana politycznie twórczość teatrów osób z niepełnosprawnością intelektualną, telenowela stanowiąca przykład kultury popularnej o uproszczonym przekazie), czy też dominującą perspektywę (sprawnych lub niepełnosprawnych postaci). Jak dowodzi przykład twórczości Teatru 21, owa estetyka może być istotnym aspektem protestu, czyli dyssensualnej działalności artystycznej, podważającym ustalone porządki i hierarchie, to znaczy zachowawczy „reżim przedstawieniowy”, który ma charakter hierarchiczny, normatywny, a zatem również wykluczający.

6 J. Rancière Dzielenie postrzegalnego: estetyka i polityka, przeł. J. Sowa, w: tegoż Dzielenie postrzegalnego: estetyka i polityka, Korporacja Ha!art, Kraków 2007, s. 70.

7 O subwersywnym wymiarze estetyki niepełnosprawności pisał między innymi Tobin Siebers w swojej książce Disability aesthectics. Według badacza niepełnosprawność, rozumiana jako forma ludzkiej różnorodności, jest źródłem nowych „perspektyw, które wystawiają na próbę założenia głęboko zakorzenione w historii estetyki. [...] Estetyka niepełnosprawności podkreśla wagę obecności niepełnosprawności w sztuce współczesnej - obecności, która kształtuje sztukę współczesną na nowe sposoby i tworzy przestrzeń dla rozwoju niepełnosprawnych artystów i niepełnosprawnej podmiotowości". T. Siebers Disability aesthectics, University of Michgan Press, Ann Arbor 2010, s. 3.

8 Kuba Mikurda podsumowuje koncepcję Rancière'a w następujący sposób: „estetyczny reżim sztuki obala normatywność i hierarchiczne dzielenie postrzegalnego, na których opiera się przedstawieniowy reżim sztuk, forsuje równość wszystkich tematów oraz odrzuca zależność między treścią a określonym sposobem przedstawienia". K. Mikurda Słownik terminów Jacques'a Rancière'a, w: J. Rancière Dzielenie postrzegalnego, s. 179.

9 Jak wyjaśnia Rancière, reżim ten ustala określoną "normatywność i stosunek między formą i materią": W „reżimie przedstawieniowym dzieła sztuki należą do sfery imitacji, a w ten sposób nie podlegają już prawom prawdy lub zwyczajnym regułom użyteczności. Są nie tyle kopiami rzeczywistości, ile sposobami narzucania formy na materię. Jako takie poddane są zbiorowi wewnętrznych norm: hierarchii gatunków, właściwemu doborowi środków wyrazu do tematu, odpowiedniości między sztukami". .). Rancière Rewolucja estetyczna i jej skutki: sploty autonomii i heteronomii, przeł. M. Kropiwnicki, w: tegoż Dzielenie postrzegalnego, s. 118-119, przyp. 3. 
Warto w tym miejscu zauważyć, że podobnie jak w Irlandii, gdzie kultura i aktywizm osób z niepełnosprawnościami rozwijają się dynamicznie od lat 90. ubiegłego wieku ${ }^{10}, \mathrm{w}$ ostatnich latach w Polsce obserwujemy zbliżone zjawiska. Należy przy tym podkreślić, szczególnie w kontekście niedawnego strajku okupacyjnego osób z niepełnosprawnościami i ich opiekunów, że protesty, w których osoby z niepełnosprawnością intelektualną wstępują przeciwko doświadczanym formom dyskryminacji, mają miejsce nie tylko w sejmie czy na ulicach, ale również w różnych obszarach kultury i sztuki. To właśnie tam od wielu lat tworzy się ferment należący do Rancière'owskiego estetycznego reżimu sztuki. W jednym $\mathrm{z}$ artykułów opublikowanych $\mathrm{w}$ zbiorze o wymownym tytule Niepetnosprawność i społeczeństwo. Performatywna siła protestu Dariusz Kosiński pisze:

Mam wrażenie, że niezależnie od ostatecznych efektów [sejmowego] protestu jego zasadniczym rezultatem może być trwałe wejście osób z niepełnosprawnościami w pole widzialności i odzyskiwanie przez nich prawa do obecności na scenie życia publicznego. To, co dzięki wieloletniej działalności takich zespołów jak Teatr 21 czy Przebudzeni, rosnącej grupy pedagogów i artystów dokonało się w ostatnich latach na scenie artystycznej, może się dzięki protestowi dokonać na scenie publicznej. Chodzi o rzecz prostą, ale nie łatwą: o uznanie podmiotowości osób z niepełnosprawnościami, zwłaszcza intelektualnymi, o zaakceptowanie ich obecności w całej jej niezwykłości. ${ }^{11}$

W przedstawionych analizach skupię się zatem na znaczeniu omawianych tekstów kultury jako form protestu wobec istniejących praktyk dyskryminacyjnych i ablestycznych sposobów myślenia o niepełnosprawności.

W Polsce seksualność osób z niepełnosprawnością intelektualną nie jest regulowana odrębnymi przepisami. Głównym problemem, z jakim borykają się te osoby, jest to, że, jak podkreśla Magdalena Hinc-Wirkus, kwestia ich

10 Pod wpływem idei zaczerpniętych między innymi ze Stanów Zjednoczonych za sprawą takich osób jak jeden z naczelnych irlandzkich niepełnosprawnych aktywistów Martin Naughton, który odwiedził USA w latach 80., w Irlandii rozwinął się wówczas ruch na rzecz niezależnego życia. siła protestu, red. E. Godlewska-Byliniak, J. Lipko-Konieczna, Fundacja Teatr 21 i Biennale Warszawa, Warszawa 2018, s. 75, https://biennalewarszawa.pl/wp-content/uploads/2019/01/niepelnosprawnosxxcxx-i-spoleczenxxstw.-performatywna-sila-protestu-1.pdf (08.07.2019). 
seksualności nadal jest uznawana za wstydliwe tabu, a brak edukacji seksualnej osób z niepełnosprawnością intelektualną, czy wręcz unikanie wszelkich związanych z tą dziedziną życia rozmów „w obawie przed niepotrzebnym zainteresowaniem tematem", jest przyczyną pogłębiających się zaburzeń w tym obszarze $^{12}$. Podstawowy problem stanowi stereotypowe postrzeganie osób z niepełnosprawnością intelektualną jako „wiecznych dzieci”, co jest częstym zjawiskiem zarówno w środowisku rodzinnym, jak i instytucjonalnym. Osoby te mają zatem często dość ograniczone możliwości seksualnej ekspresji i nawiązywania bezpiecznych, dobrowolnych stosunków seksualnych.

W tak zarysowanym kontekście warto również podkreślić to, że choć polskie prawo nie reguluje bezpośrednio kwestii seksualności osób z niepełnosprawnością intelektualną, w Kodeksie rodzinnym i opiekuńczym istnieje zapis, który, jak dowodzi Wojciech Załuski, stanowi niechlubną pozostałość dawnych praktyk eugenicznych ${ }^{13}$. Zgodnie z polskim prawem:

Nie może zawrzeć małżeństwa osoba dotknięta chorobą psychiczną albo niedorozwojem umysłowym. Jeżeli jednak stan zdrowia lub umysłu takiej osoby nie zagraża małżeństwu ani zdrowiu przyszłego potomstwa i jeżeli osoba ta nie została ubezwłasnowolniona całkowicie, sąd może jej zezwolić na zawarcie małżeństwa. ${ }^{14}$

W praktyce oznacza to, że podczas rozmowy z osobami planującymi wstąpić w związek małżeństwa pracownik urzędu stanu cywilnego dokonuje oceny ich stanu „zdrowia lub umysłu” i w razie jakichkolwiek zastrzeżeń może

12 M. Hinc-Wirkus „Upośledzony” seks, czyli o seksualności osób z niepełnosprawnościq w Polsce, "Czasopismo Pedagogiczne" $2017 \mathrm{nr}$ 1/4, S. 36.

13 W. Załuski Z historii eugeniki, 14.05.2018, https://www.youtube.com/watch?time_continu$\mathrm{e}=2703 \& \mathrm{v}=y Z 1 V H q p e T z A \& f e a t u r e=e m b \_t i t l e$ (08.11/2019). Dyskurs eugeniczny pojawia się również w polskich dyskusjach dotyczących seksualności i praw reprodukcyjnych osób z niepełnosprawnością intelektualną. Jak kilka lat temu pisały Paulina Szkudlarek i Sławomira Raczyńska: „Choć mamy 2015 rok, nader często w dyskusjach o seksualności osób z tymi typami niepełnosprawności pojawia się dyskurs eugeniczny, który idzie w parze z praktyką odbierania prawa decydowania o własnym ciele tym jednostkom, których liczebność należy po prostu ograniczyć poprzez uniemożliwienie reprodukcji (to kwestia żywa również na polskim gruncie - wystarczy przywołać głośną sprawę Wioletty Szwak)". P. Szkudlarek i S. Raczyńska Zboczone kaleki. Poza sanonormatywnościq i somatoestetykq, Projekt Kobieta Nieheteronormatywna (2014-2015), s. 9, http://www.knh.vxm.pl/images/zboczonekaleki2.pdf(08.11.2019).

14 Pełny tekst kodeksu jest dostępny na stronie http://prawo.sejm.gov.pl/isap.nsf/download. xsp/WDU19640090059/U/D19640059Lj.pdf. 
odmówić udzielenia ślubu i skierować sprawę do sądu. Pomimo zapowiedzi zmian w prawie stojącym w sprzeczności z Konwencją ONZ o prawach osób niepełnosprawnych, kontrowersyjny zapis nadal obowiązuje.

Do tej kwestii w polskiej kulturze popularnej odnieśli się między innymi twórcy serialu Klan, w którym jedna z postaci - Maciej Lubicz (Piotr Swend), mężczyzna z zespołem Downa - decyduje się oświadczyć swojej dziewczynie Martynie Czerskiej. Nie uzyskują jednak zgody sądu na zawarcie małżeństwa. Sędzia uznaje, że Maciej i Martyna cechują się wysoką niesamodzielnością, brakiem doświadczenia w samodzielnym życiu i brakiem możliwości podjęcia pracy zarobkowej oraz wymagają stałej pomocy osób trzecich w podstawowych czynnościach życiowych (odcinek 2331) ${ }^{15}$. W reportażu opublikowanym w „Tygodniku Przegląd” Ewa Wołkanowska-Kołodziej pisze:

Problemem jest nie tylko urzędnik, który takim narzeczonym ślubu nie da, albo kelner, który na pierwszej randce nie przyniesie im wina. Chodzi o to, że w Polsce 20- czy 40-letni Maciej jest Maciusiem ze śliniaczkiem z Myszką Miki. A Martyna - Martynką, która nie potrafi przykleić podpaski, bo całe życie na zajęciach plastycznych kleiła bałwanki. Ich seksualność straszy rodziców [...], krępuje opiekunów w ośrodkach [...], gorszy obserwatorów [...]. A jak coś straszy, krępuje i gorszy, to najlepiej udawać, że nie istnieje. ${ }^{16}$

Autorka ma poniekąd rację. Maciej bywa infantylizowany przez otoczenie, a w szczególności przez swoją matkę. W odcinku 2183 zaniepokojeni decyzją o ślubie rodzice zabierają syna do seksuolożki, która zwraca się do niego „panie Macieju”; Grażyna Lubicz natychmiast dodaje: „syn woli, kiedy zwraca się do niego «Maćku»". Matka nie potrafi rozmawiać z synem o seksie. Temat ten podejmuje dopiero w odcinku 3194, w którym stara się mu wytłumaczyć, jaką rolę w jego życiu odegrał biologiczny ojciec, nieporadnie wykorzystując metaforę precla i pieca. Grażyna Lubicz przechodzi jednak pewną metamorfozę i zaczyna powoli rozumieć pragnienia syna oraz zdawać sobie sprawę $\mathrm{z}$ ableistycznego wymiaru polskich zapisów prawnych. W odcinku 2329, po rozmowie Macieja i Martyny z biegłym psychologiem, podkreśla, że „bardzo

15 Wszystkie omawiane odcinki serialu Klan są dostępne na platformie TVP, https://vod.tvp.pl/ website/klan,1667844.

16 E. Wołkanowska-Kołodziej Seks niepełnoprawny, "Tygodnik Przegląd" 31.03.2014, https://www. tygodnikprzeglad.pl/seks-niepelnoprawny/ (08.07.2019). 
wiele par pełnosprawnych umysłowo nie rozumie tak jasno swoich wyobrażeń, celów jak oni".

Ostatecznie przykład Macieja pod wieloma względami dowodzi,że zespół Downa nie jest przyczyną jego niesamodzielności, tylko że niepełnosprawność ta jest w dużym stopniu wynikiem określonego sposobu wychowania w szkole i rodzinie. Tym, co upośledza, jest przede wszystkim otoczenie, które nie starało się przygotować mężczyznę do samodzielności. Problemem nie są zdolności intelektualne Macieja, ale to, że przez cały czas był postrzegany jako niesamodzielne dziecko. Bohater traktuje zatem wyrok sądu jako wyzwanie i w kolejnych odcinkach samodzielnie uczy się gotować, a nawet zakłada własną preclownię. Po licznych perypetiach sercowych i zawodowych ponownie postanawia zawrzeć związek małżeński z Martyną w Kanadzie.

Klan pokazuje, że chcąc korzystać z pełni praw obywatelskich, osoby z niepełnosprawnością intelektualną muszą dowieść swojej samodzielności, spełniając dużo wyższe wymogi niż osoby nieposiadające tego rodzaju dysfunkcji. Wielce problematyczne w tym kontekście wydaje się traktowanie kategorii samodzielności, rozumianej jako niekorzystanie ze stałej pomocy osób trzecich, jako istotnego warunku, który powinna spełniać jednostka, aby mogła sama o sobie decydować. David T. Mitchell i Sharon L. Snyder nazywają tego rodzaju postawę neoliberalnym „ablonacjonalizmem” (ablenationalism). Jak wyjaśniają,

ablonacjonalizm łączy cechy nacjonalizmu rozumianego jako „głębokie horyzontalne poczucie wspólnotowości" z normami sprawności, które wydają się w naturalny sposób jednoznaczne z przywilejami obywatelskimi [...]. Funkcjonalność, sprawność i wygląd są traktowane jako czynniki determinujące uczestnictwo w powierzchownych identyfikacjach charakterystycznych dla nacjonalizmu. ${ }^{17}$

Innymi słowy, ablonacjonalizm jest jedną z form współczesnej sprawnościocentrycznej biopolityki, podporządkowanej neoliberalnemu modelowi samowystarczalnej, wydajnej i sprawnej jednostki. Mitchell i Snyder uważają taki model za dyskryminujący i szkodliwy. Podkreślają, że „tym, co tracimy w relacjach mieszczących się w standardach neoliberalnej normalności, jest znajomość alternatywnych map wspólnego życia kreślonych przez relacje

17 D.T. Mitchell, S.L. Snyder The biopolitics of disability: neoliberalism, ablenationalism, and peripheral embodiment, University of Michigan Press, Ann Arbor 2015, s. 13. 
osób niepełnosprawnych, które wyraźnie opierają się na współzależności, oraz nienormatywne formy ucieleśnienia"18. Do tego rodzaju map odwołuje się również Lennard J. Davis, gdy pisze o swojej koncepcji dysmodernizmu „stawiającego sobie za cel stworzenie nowej kategorii, której podstawę stanowi częściowy, niekompletny podmiot, realizujący się nie tyle poprzez autonomię i niezależność, ile przez zależność i współzależność"19. Taka relacja nie może jednak nosić znamion infantylizacji czy protekcjonalności, ale musi zakładać uznanie sprawczości i podmiotowości jednostki zależnej ${ }^{20}$. Podobnej relacji nie udaje się do końca stworzyć w Klanie.

Trudno jednak zgodzić się z Anną Dwojnych, która stwierdza, że postać Macieja Lubicza umacnia „najgorsze stereotypy dotyczące osób niepełnosprawnych"21. Autorka powołuje się na badania Beaty Łaciak, która pokrótce analizuje zarówno pozytywne, jak i negatywne reakcje widzów na sposoby przedstawienia niepełnosprawności intelektualnej w Klanie. Przede wszystkim jednak podkreśla własne argumenty, które pod wieloma względami powielają pewne ableistyczne sposoby myślenia o szeroko pojętej neuroróżnorodności:

Po pierwsze, serial nieumyślnie ośmiesza mongolizm i osoby nim dotknięte [sic!]. Po drugie, podaje w wątpliwość etyczność producentów serialu, angażujących niepełnosprawną osobę do grania w scenach trudnych emocjonalnie. Aktorzy współpracujący ze Swendem są zgodni, że mężczyzna nie do końca zdaje sobie sprawę z fikcyjności serialu. Co więcej, sam aktor wydaje się nie oddzielać swojej tożsamości od granej przez siebie postaci. ${ }^{22}$

Nie jest moim celem dowodzenie, że Piotr Swend jest zawsze świadomy różnicy pomiędzy fikcyjnym światem przedstawionym a rzeczywistością.

18 Tamże, s. 3.

L.J. Davis Bending over backwards: disability, dismodernism, and other difficult positions, New York University Press, New York 2002, s. 30.

Więcej na temat relacji zależności w kontekście niepełnosprawności pisze na przykład E.F. Kittay The Ethics of Care, Dependence, and Disability, "Ratio Juris" $2011 \mathrm{nr}$ 24/1, http://evafederkittay.com/wp-content/uploads/2015/01/The-ethics-of-care.pdf (08.07.2019). w serialach, "Fragile" $2017 \mathrm{nr} 1 / 35$, s. 83. 
Pragnę przede wszystkim zwrócić uwagę na pewne podwójne standardy, które uwidaczniają się w przytoczonych powyżej słowach. Jeżeli bowiem przyjrzymy się różnym metodom psychologicznego aktorstwa realistycznego, sięgając do jego korzeni, czyli do metody Stanisławskiego (czy też późniejszej, bardziej radykalnej metody Strasberga), okaże się, że owo zatracenie się w roli, polegające na współodczuwaniu z postacią, a wręcz prawie staniu się nią, często uważa się za wyraz aktorskiej doskonałości. Co więcej, słowa Dwojnych można również odczytywać jako wyraz niskich oczekiwań i protekcjonalności wobec aktorek i aktorów z niepełnosprawnością intelektualną, którzy nie powinny występować „w scenach trudnych emocjonalnie".

Opinie o tym, że Swend nie radzi sobie z rolą i dlatego "serialowy obraz niepełnosprawności przynosi szkodę samym zainteresowanym"23, były również wygłaszane przez internautów cytowanych przez Łaciak. Szczególnie ciekawe wydają się wypowiedzi, które autorka klasyfikuje jako „dekodowanie wynegocjowane [...]. Widzowie mają świadomość intencji nadawcy, ale nie zgadzają się ze sposobem ich kodowania" ${ }^{24}$. Widać w nich wyraźnie społeczną hipokryzję i sposób myślenia charakterystyczny dla reakcyjnego Rancière'owskiego reżimu przedstawieniowego sztuk, który ściśle określa, jakie tematy sztuka powinna poruszać, w jakim wymiarze i w jaki sposób. Z dwóch pierwszych przytoczonych przez Łaciak wypowiedzi wynika bowiem, że aktorzy z niepełnosprawnością intelektualną są mile widziani w serialach, o ile ich historie nie są zbyt wyeksponowane i o ile będą wpisywali się w pewne ableistyczne standardy wyglądu i ekspresji. O tym, że Swend nie radzi sobie z rolą, ma zatem świadczyć to, że aktor jąka się i ma zeza ${ }^{25}$.

Postać Macieja w Klanie i jego perypetie sercowe spotkały się zatem z dużo większą krytyką niż irlandzka sztuka Sanctuary, choć i w jej przypadku aktorzy nie do końca wpisywali się w standardy tradycyjnego aktorstwa. Duże wyzwanie stanowiła znaczna ilość tekstu, którego nie byli w stanie nauczyć się na pamięć, w związku z czym Petal Pilley, dyrektorka artystyczna Blue Teapot, przed każdym spektaklem informowała widzów, że aktorom w razie

23 B. Łaciak Kwestie społeczne w polskich serialach obyczajowych - prezentacje iodbiór, Wydawnictwo Akademickie Żak, Warszawa 2013, s. 331.

24 Tamże, s. 332. 
potrzeby będzie pomagał sufler. Jak podaje Christian O'Reilly, tego rodzaju rozwiązanie spotkało się z pełną aprobatą odbiorców ${ }^{26}$.

Brak głosów krytycznych w tym wypadku może po części wiązać się z tym, że spektakl obejrzała grupa widzów, którą zwykło się postrzegać jako bardziej elitarną i lepiej zaznajomioną z estetyką niepełnosprawności. Nie oznacza to jednak, że głosy krytykujące fakt, że aktorzy z niepełnosprawnością intelektualną odgrywają role w przedstawieniach poruszających zagadnienia skomplikowane i emocjonalnie wymagające, nie pojawiają się poza granicami Polski, również w odniesieniu do sztuki postrzeganej jako wysoka. Warto tutaj przytoczyć przykład słynnego australijskiego teatru osób z niepełnosprawnością intelektualną Back to Back Theatre. Podczas spotkania z twórcami zorganizowanego po jednym ze spektakli w Brukseli pewien widz stwierdził: „Nie wierzę, że ci ludzie zrobili ten spektakl [...]. Pracowałem z tego rodzaju ludźmi i nie sądzę, żeby byli do tego zdolni". Odpowiedział mu aktor Scott Price: „Cóż, gościu, chyba powinieneś stąd w tej chwili wyjść, bo to, co powiedziałeś, jest złe i obraźliwe"27.

Podobnie obraźliwe wydają się niektóre z wcześniej wspomnianych komentarzy na temat kompetencji aktorskich Swenda. W przypadku Klanu warto bowiem podkreślić, że sposób przedstawienia problemów, z którymi boryka się Maciej Lubicz, pod wieloma względami nie jest bardziej „niefortunny" niż to, jak serial pokazuje inne ważne wydarzenia z życia Lubiczów i pozostałych bohaterów telenoweli. Jak trafnie zauważa Dwojnych: „Opery mydlane są produkcjami niskobudżetowymi o słabym poziomie realizacji i gry aktorskiej"28. Przedmiotem drwin internautów jest zatem nie tylko Maciek, ale też inne postaci i rozwiązania scenarzystów, które sprawiają, że serial pod wieloma względami wydaje się rodzajem naiwnej, ,,miłej bajki dla dorosłych, opowiadającej o świecie lepszym i piękniejszym niż ten, który znają"29. Fakt, iż internauci naśmiewają się z niepełnosprawnego aktora być

O swojej pracy nad sztuką Christian O’Reilly opowiedział w ramach wykładu wygłoszonego W 2015 r. na Uniwersytecie Łódzkim podczas konferencji "Negotiating Space for (Dis)ability in Drama, Theatre, Film and Media". Transkrypcja wykładu ukaże się w tym roku w książce Disability and dissensus: Strategies of disability representation and inclusion in contemporary culture, red. K. Ojrzyńska, M. Wieczorek, Brill, Leiden 2020,

Cyt. za: G. Coslovich The elephant in the room, „The Sidney Morning Herald" 24.09.2011, https:// www.smh.com.au/entertainment/theatre/the-elephant-in-the-room-20110923-1kout.html.

A. Dwojnych ZespółDowna i popkultura, s. 87. 
może częściej niż z innych, obnaża jedynie ich mocno zakorzenione uprzedzenia oraz pokazuje, że niepełnosprawność Swenda wiąże się ze szczególnie silnym piętnem społecznym.

Współcześni badacze, którzy zajmują się analizą różnorodnych kulturowych przedstawień niepełnosprawności, poświęcają wiele uwagi temu, jak wybrane teksty kultury podważają utarte sposoby myślenia o niepełnosprawności. Są to przede wszystkim stereotypy związane z modelem medycznym, zgodnie z którym niepełnosprawność jest formą braku i deficytu, przez co bywa ukazywana głównie jako źródło cierpienia. Nie oznacza to, że wszelkie przedstawienia niepełnosprawności jako doświadczenia związanego z bólem czy też traumą są z gruntu nieprawdziwe czy niewłaściwe. Chodzi raczej o to, że tego rodzaju obrazy zdominowały naszą kulturę i zdeterminowały pewien jednorodny, negatywny sposób postrzegania bardziej złożonego zjawiska. Podobny problem dotyczy uczestnictwa aktorów z niepełnosprawnością intelektualną w kulturze. Ich percepcja społeczna nie ulegnie znacznej zmianie, jeżeli będą występować jedynie w niskobudżetowych operach mydlanych i spektaklach realizowanych w ramach zajęć terapeutycznych. Niezmiernie ważne wydają się zatem dwa kolejne teksty kultury, które pragnę umówić. Są to polskie realizacje teatralne, które poruszają zagadnienie seksualności osób z niepełnosprawnością intelektualną dużo dobitniej i w bardziej subwersywny, złożony i wielowymiarowy sposób niż telenowela Klan.

Pierwszym przykładem jest sceniczna adaptacja sztuki Radosława Paczochy Moja sprawa (2015) w reżyserii Iwony Siekierzyńskiej i wykonaniu teatru Biuro Rzeczy Osobistych (BRO), założonego w 1998 roku przy Polskim Stowarzyszeniu na Rzecz Osób z Upośledzeniem Umysłowym Koło w Gdyni przez Zbigniewa Biegajłę, oligofrenopedagoga oraz reżysera teatru dzieci i młodzieży. W ostatnich latach BRO stopniowo odchodzi od głęboko zakorzenionej na gruncie polskim koncepcji konwencjonalnej teatroterapii, w kierunku działalności artystycznej otwartej na spotkania z publicznością ${ }^{30}$. Spektakl Moja sprawa można uznać za krok milowy w tych dążeniach w dużej mierze dzięki decyzji Biegajły, aby zaangażować w jego realizację profesjonalnych praktyków teatru: reżyserkę Iwonę Siekierzyńską, scenografkę Izabelę Stronias oraz zawodowych aktorów Aleksandrę Nieśpielak i Krzysztofa Grabowskiego. Jak tłumaczy Biegajło: „Chodziło o to, by stworzyć taką przestrzeń, by aktorzy powiedzieli własnym głosem o swoich sprawach,

30 Fragment opisu ze strony internetowej teatru (zakładka "O nas”): http://www.tbro.psonigdynia.pl/o_nas.html. 
i szukaliśmy osób, które mogłyby nam w tym pomóc"31. Spektakl był zatem nie tylko miejscem spotkania widzów i aktorów, ale również okazją do dialogu dwóch światów aktorskich.

Spektakl Moja sprawa pokazuje historię zakazanej miłości, odnosząc się do kwestii praw osób z niepełnosprawnością intelektualną do samostanowienia, podejmowania samodzielnych decyzji i ponoszenia ich konsekwencji. Główną osią konfliktu jest ciąża Wiktorii, osoby z niepełnosprawnością intelektualną. Jest ona owocem związku bohaterki z jej niepełnosprawnym partnerem Adamem, z którym uczęszcza na zajęcia teatralne.

Inscenizacja sztuki Paczochy zadaje podstawowe pytanie o to, czym jest niepełnosprawność. Ukazuje ją przede wszystkim jako niemożność spełniania tradycyjnie pojmowanych ról społecznych, przypisanych binarnie określonym płciom. Widać to wyraźnie w scenie, w której uczestnicy warsztatów teatralnych uczą się wiązać krawaty, aby stać się „prawdziwymi mężczyznami". Paradoksalnie niepełnosprawnym mężczyznom zadanie wychodzi znacznie lepiej niż sfrustrowanemu, sprawnemu terapeucie. Spektakl podkreśla w ten sposób sztuczność i umowność różnorodnych konstruktów społeczno-kulturowych.

Moja sprawa ukazuje również infantylizację i uprzedmiotowienie osób niepełnosprawnych intelektualnie w polskim społeczeństwie. Jest to szczególnie widoczne w scenie przedstawiającej wizytę u ginekologa. Przystępując do badania, lekarz zwraca się nie tyle do pacjentki, ile do jej matki i to z nią omawia dostępne opcje: możliwość aborcji lub urodzenia przez kobietę dziecka, którym następnie zajmie się jej matka lub rodzina zastępcza. Wiktoria zostaje w tej rozmowie pominięta i uprzedmiotowiona - zredukowana do roli wadliwego inkubatora. Ciąża jest traktowana jako problem matki bohaterki, a nie sprawa dotycząca przede wszystkim jej samej. Z niesprawiedliwości zaistniałej sytuacji doskonale zdaje sobie sprawę matka Wiktorii. Otwarcie stwierdza, że odbiera swojemu dziecku głos w najważniejszych sprawach, które bezpośrednio go dotyczą. Kobieta uważa, że tego rodzaju ubezwłasnowolnienie nie powinno mieć miejsca, a jednak nie potrafi czy też nie ma wystarczająco dużo siły i odpowiednich środków, aby walczyć z zastanymi sposobami myślenia o niepełnosprawności.

W jednej z kluczowych scen spektaklu Wiktoria przeciwstawia się temu, żeby decyzję o jej losie podejmowały osoby trzecie: lekarze, terapeuci czy

31 Cyt. za Ł. Rudziński Spektakl o ciq̨ży niepełnosprawnych, „Dziennik Teatralny” 04.11.2015, http:// www.dziennikteatralny.pl/artykuly/spektakl-o-ciazy-niepelnosprawnych.html (08.07.2019). 
matka - krzyczy: „Urodzę to dziecko!”. Ostatecznie matka Wiktorii nie podejmuje decyzji o aborcji. Pod koniec spektaklu widzowie są świadkami sceny, w której główna bohaterka tańczy w zrobionym z firanki welonie wraz ze swoim partnerem. Ta niema projekcja marzeń o stworzeniu rodziny kończy się krótką pantomimą, w której nowo narodzone dziecko zostaje odebrane matce i jest przekazywane $\mathrm{z}$ rąk do rąk. Rzeczywistość bezlitośnie wkracza zatem w sferę marzeń. Bezgłośna pantomima sugeruje, że cały proces odbywa się automatycznie i nie podlega dyskusji.

Choć sztuka Paczochy i wspomniany wcześniej dramat O'Reilley'a mają wiele punktów wspólnych, odzew społeczny w Polsce zdecydowanie różnił się od tego, który można było zaobserwować w Irlandii. Na szczególną uwagę zasługuje sprawozdanie z rozmowy z widzami, która odbyła się po jednym ze spektakli, opublikowane w „Gazecie Pomorskiej” w artykule o wymownym tytule: Problemy seksualne osób z zespołem Downa nadal nie rozwiąane. Rodzice szukaja pomocy ${ }^{32}$. To bardzo ważne, że taka rozmowa miała miejsce. Z artykułu można jednak wywnioskować, że dyskusja skupiała się przede wszystkim na kwestii eliminacji seksu jako problemu z życia osób z niepełnosprawnością intelektualną. Mówiono o środkach obniżających popęd płciowy oraz o zapobieganiu ciąży osób z niepełnosprawnością intelektualną. Nie obyło się też bez poruszenia moralnych aspektów aborcji. Jednocześnie, co wydaje się szczególnie ironiczne, biorąc pod uwagę tytuł sztuki, z artykułu wynika, że rozmowa odbyła się prawie wyłącznie w gronie rodziców i opiekunów. Brakło w niej głosów osób z niepełnosprawnością intelektualną, których omawiane problemy dotyczą bezpośrednio. Osoby te były jedynie przedmiotem, a nie podmiotami w dyskusji. Uzasadnione wydaje się zatem pytanie o przyczyny, które spowodowały, że spektakl nie wyszedł do końca poza Rancière’owski „przedstawieniowy reżim sztuki." Można by zaryzykować tezę, iż dramat Paczochy nie dokonuje pełnego upodmiotowienia występujących w nim niepełnosprawnych postaci i nie pozwala w pełni wybrzmieć ich głosom, ponieważ kładzie zbyt duży nacisk na perspektywę osób sprawnych: matki Wiktorii i jej pedagoga. To właśnie oni zdominowali sztukę na poziomie werbalnym. Dramat kończy zatem monolog terapeuty, który przełamuje czwartą ścianę. Postać dzieli się z widzami przede wszystkim swoją bezsilnością wobec

32 J. Zielazna Problemy seksualne osób z zespołem Downa nadal nie rozwiq̨zane. Rodzice szukajq pomocy, "Gazeta Pomorska" 23.03.2016. http://plus.pomorska.pl/wiadomosci-z-kraju-i-swiata/a/problemy-seksualne-osob-z-zespolem-downa-nadal-nierozwiazane-rodzice-szukajapomocy,9772471 (08.07.2019). 
ustalonego porządku świata, z którym - podobnie jak matka Wiktorii - nie ma siły walczyć. Choć nie potrafi przestać myśleć o niepełnosprawnych bohaterach, nie jest w stanie znaleźć lepszego zakończenia dla ich historii. Tego rodzaju zabieg sprawia, że widz identyfikuje się przede wszystkim ze sprawnymi postaciami, a nie z Wiktorią czy Adamem.

Gesty i słowa protestu niepełnosprawnych aktorów wobec zastanej, dyskryminującej rzeczywistości wybrzmiewają ze znacznie większą siłą w ostatniej części teatralnego serialu realizowanego przez warszawski Teatr 21, zatytułowanej Klauni, czyli o rodzinie. Odcinek3 (2017). Należy podkreślić, że już sam system pracy prowadzonego przez Justynę Sobczyk profesjonalnego zespołu aktorskiego, w którego skład wchodzą aktorzy i aktorki z zespołem Downa i autyzmem, stanowi skuteczną formę uwłasnowolnienia. Pod wieloma względami wpisuje się on bowiem w konwencję teatru współtworzonego (devised theatre), który Alison Oddey definiuje, wymieniając szereg charakterystycznych czynników i elementów:

proces (odnalezienie dróg i sposobów, dzięki którym zespół wyruszy we wspólną artystyczną podróż), kooperacja (współpraca), wielowymiarowość wizji (połączenie wielu opinii, wierzeń, doświadczeń życiowych i podejść do zmieniającego się świata) oraz stworzenie dzieła artystycznego. ${ }^{33}$

Są to elementy, które wyraźnie widać w metodach pracy Teatru 21 opisywanych przez Justynę Sobczyk jako „wspólne błądzenie” - wspólne poszukiwanie nowych dróg i szlaków ${ }^{34}$.

Kluczowym problemem poruszonym w Klaunach są kwestie związane z niezależnym życiem osób z niepełnosprawnością intelektualną w Polsce oraz krytyka krótkotrwałych projektów i braku długofalowej, dobrze przemyślanej polityki zmian w tym obszarze. Oś konfliktu w spektaklu została zbudowana wokół projektów zakładających prowadzenie tak zwanych monti, "Polskie radio" 21.12.2015, https://polskieradio24.pl/130/4462/Artykul/1560536,Klauniomawia w wywiadzie przeprowadzonym przez Grzegorza Giedrysa: J. Sobczyk U nas aktorzy wychodzą z ról, "Gazeta Wyborcza: Tygodnik Toruń" 01.07.2016, http://torun.wyborcza.pl/torun/1,70710,20328139,justyna-sobczyk-aktorzy-wychodza-z-rol.html (08.07.2019). 
mieszkań treningowych. Jak zauważają Ewelina Godlewska-Byliniak i Justyna Lipko-Konieczna:

Trening w tego rodzaju mieszkaniach trwa od dwóch tygodni do trzech miesięcy. O pobycie tam mówi się często jak o turnusie, jakby zapominając, że samodzielne mieszkanie dla osób z niepełnosprawnością, a przede wszystkim dla osób z niepełnosprawnością intelektualną, to spełnienie największej życiowej potrzeby. ${ }^{35}$

Aktorzy Teatru 21 głośno i dobitnie wyrażają swój sprzeciw wobec takiego stanu rzeczy.

Od strony formalnej ciekawym rozwiązaniem wydaje się to, że w spektaklu również role osób sprawnych (Trenera czy Pani Prezydent) odgrywają osoby z niepełnosprawnością intelektualną. Wykorzystana strategia, polegająca na odwróceniu „ukaleczania”, zachęca widzów do refleksji nad umownością normy medycznej, która wyznacza granicę między osobami sprawnymi a tymi, które zwykło się uznawać za niepełnosprawne. W świecie przedstawionym niepełnosprawność to "łatka" przypięta wybranym postaciom, które jednak w zasadzie nie różnią się znacząco od postaci uznawanych za sprawne, ponieważ wszystkie role odgrywają należący do szerokiego spektrum neuroróżnorodności aktorzy T21. Odwrócone „ukaleczenie” przypomina zatem widzom o tym, że niepełnosprawność, rozumiana jako niekompletność i niesamowystarczalność, jest uniwersalną cechą współczesnej jednostki, o czym pisze między innymi wspomniany wcześniej Lennard J. Davis ${ }^{36}$.

Spektakl podkreśla również podobieństwa między społecznymi i kulturowymi konstrukcjami płci i niepełnosprawności. Postaci uczestników projektu zostają bowiem wtłoczone w tradycyjne, uproszczone i zinfantylizowane role genderowe. Ich sztuczność podkreślają peruki, które uczestnicy programu przywdziewają przed wejściem do mieszkania treningowego: mężczyzna otrzymuje perukę czarną, kobieta zaś - jasną. Następnie dostają prezent od Pani Prezydent: niebieskie i różowe kapcie. Paradoksalnie role, które z perspektywy studiów feministycznych i genderowych jawią się jako pod wieloma względami opresyjne, w Klaunach są przedstawione jako szczyt marzeń.

E. Godlewska-Byliniak, J. Lipko-Konieczna Publiczne - prywatne: teatralna gra z niepełnosprawnościq, w: 21 myśli o teatrze, red. E. Godlewska-Byliniak, J. Lipko-Konieczna, Fundacja Win-win, Warszawa 2016, s. 27. 
Spektakl odzwierciedla pragnienia samych aktorów, a jednocześnie jest próbą zgłębienia przez nich kwestii tworzenia relacji osobistych, czyli tematu, o którym wiedzę, podobnie jak Maciek Lubicz z Klanu, czerpali w dużej mierze z przekazywanych im dotychczas „uproszczonych komunikatów”37. W wywiadzie z Magdaleną Rigamonti Justyna Sobczyk wspomina, że spektakl Klauni podkreśla „role tradycyjne, które my już często porzucamy, bo już one są dla nas jakimiśs skorupami, a [...] nasi aktorzy by chętnie te skorupki po prostu też wzięli", choć nadal pozostają one dla nich niedostępne ${ }^{38}$. Na przykład w jednej z początkowych scen pierwsza uczestniczka projektu z zapałem prasuje ubrania do wtóru I Want to Break Free zespołu Queen. Podczas gdy w kultowym teledysku Freddy Mercury w parodystyczny sposób wciela się w panią domu z brytyjskiej telenoweli, śpiewając o pragnieniu zrzucenia jarzma kobiecych prac domowych, w Klaunach fartuch i deska do prasowania są atrybutami symbolizującymi upragnioną wolność.

Wjednej ze scen osoby, które nie dostały się do mieszkania treningowego, protestują, skandując pod drzwiami: „Nie ma wolności bez samodzielności”. Podobnie jak w odcinkach Klanu pokazujących reakcję Macieja Lubicza na negatywne orzeczenie sądu siłą motywującą postaci do protestu jest zarówno chęć wyzwolenia od stereotypu „wiecznego dziecka”, jak i fakt przyswojenia neoliberalnego ideału niezależnej, samowystarczalnej jednostki. Samodzielność, czyli radzenie sobie bez pomocy innych, jawi się zatem jako niepodważalny warunek, który należy spełnić, aby móc samemu o sobie decydować.

Ważną rolę w spektaklu odgrywają kwestie seksualności i cielesnej bliskości osób z niepełnosprawnością intelektualną, które budzą eugeniczne obiekcje sprawnych postaci. Kiedy pierwsza z par zajmuje mieszkanie treningowe, elementem wystroju, na który od razu zwracają uwagę, jest łoże małżeńskie, co spotyka się z ostrym komentarzem ze strony Pani Prezydent: „Mam nadzieję, że nie będzie z tego dzieci”. Seksualność nie jest elementem „dorosłego życia", które uczestnicy projektu powinni eksplorować, dlatego przed opuszczeniem mieszkania Asystentka Pani Prezydent ostrzega nowych domowników: „będziemy państwa obserwować". W mieszkaniu treningowym nie ma zatem miejsca na prywatność - to miejsce iście Foucaultowskiego nadzoru i dyscypliny. Kiedy tylko para doświadcza momentu bliskości, siedząc na kanapie, ich romantyczny pocałunek natychmiast brutalnie przerywa odgłos gwizdka Trenera.

37 J. Sobczyk, M. Rigamonti W poniedziałek u Rigamonti.

38 Tamże. 
O seksualności osób z niepełnosprawnością intelektualną przypomina nam również scena, w której jedna z postaci (Aleksander Orliński) staje na cyrkowym podeście, gdzie chwilę wcześniej występował brzuchomówca z pluszową małpą, i wykonuje striptiz, zrzucając z siebie kolejne koszulki z hasłami kolejnych projektów. Obnaża w ten sposób nieskuteczność polityki antywykluczeniowej, która przez ostatnie dekady jedynie maskowała problem wykluczenia z przestrzeni i życia publicznego ${ }^{39}$, zamiast starać się go rozwiązać. Choć jednocześnie obnaża znacznie więcej. W chwili gdy zrzuca ostatnią koszulkę, widzom ukazuje się zgrabne ciało młodego mężczyzny. Pomimo parodystycznego wydźwięku sceny, jest to ciało, które w dużej mierze wpisuje się w standardy tradycyjnie pojmowanej atrakcyjności. Na co dzień pozostaje ono jednak ukryte, ponieważ uznaje się je za nieatrakcyjne, wadliwe i nienormalne.

Podobną wymowę, a jednocześnie parodystyczny wydźwięk ma scena, w której dwie postaci odziane w szczelne białe kombinezony z kapturami eksplorują małżeńskie łoże. Przypominają astronautów stawiających pierwsze kroki w nieznanej przestrzeni. Podczas eksplorowania przez nie łóżka, części ciała partnera i różnych układów cielesnej bliskości na scenę wchodzi aktorka Teresa Foks. Odziana w niebieską słomianą spódniczkę i kwiaty nawiązuje do Statku miłości (2013), jednego z poprzednich odcinków teatralnego serialu, który traktował o potrzebie kochania i bycia kochanym. Pieśń Teresy, wykonana w znanym tylko jej języku, jest zatem swoistym hymnem miłości niezrozumiałej dla dużej części społeczeństwa.

Owocem erotycznego zbliżenia jest ciąża bohaterki. Jedna z aktorek nakłada na siebie gumowy brzuch, który staje się coraz pełniejszy. Scenę, w której pozostali aktorzy gromadzą się na łóżku i dotykają ciążowego brzucha postaci, przerywa Pani Prezydent, ogłaszając: „Zamykam ten cyrk”, a z dmuchanego łoża małżeńskiego zostaje spuszczone powietrze. W zderzeniu z rzeczywistością i rządzącymi nią ablonacjonalistycznymi zasadami pragnienia postaci i aktorów pryskają niczym mydlane bańki.

Owe pragnienia znajdują ponownie wyraz w końcowej projekcji krótkiego czarno-białego filmu. Widzimy w nim odzianą w eleganckie dziewiętnastowieczne stroje parę, która spaceruje po parku z niemowlęcym wózkiem. Zbliżenie pokazuje nam, że to aktorzy Teatru 21. Obecna w filmie stylizacja wyraźnie sugeruje, że to jedynie projekcja marzeń.

39 P. Morawski Nie ma wolności bez samodzielności. „Klauni, czyli o rodzinie”, w: Odzyskiwanie obecności, s. 346. 
Podsumowując, ostatni spektakl Teatru 21, podobnie jak pozostałe przedstawienia warszawskiego zespołu, daje niepełnosprawnym aktorom przestrzeń do tego, aby tworzyć - performować - siebie na nowo przed oczami widzów. Ważnym aspektem tego upodmiotowienia jest to, że w Klaunach dominującą perspektywą jest doświadczenie osób niepełnosprawnych, które otwarcie manifestują swoją seksualność oraz potrzeby osobiste i społeczne, cielesne i emocjonalne. Jednocześnie w groteskowy sposób wyśmiewają projekty charytatywne, przepełnione wzniosłymi, modnymi hasłami, za którymi kryje się chęć utrzymania istniejącego status quo. Używając słów Rancière’a, można powiedzieć, że Klauni posiadają silny dyssensualny wymiar polityczny. Według Rancière'a polityka dotyczy bowiem „tego, co widzimy i co możemy o tym powiedzieć, tego, kto ma kompetencje, aby widzieć, i predyspozycje, aby mówić"40. Teatr 21 pokazuje niepełnosprawność intelektualną jako cenną formę ludzkiej różnorodności, osoby z niepełnosprawnością zaś jako jednostki seksualne. Jego twórczość wpisuje się zatem w Rancière'owską wizję polityki jako „dyssensualnego procesu”, w obrębie którego „konstytuują się jednostkowe i zbiorowe tożsamości"41.

W kontekście omawianych zagadnień warto również zwrócić uwagę na to, że spektakl Klauni w bardzo subtelny sposób wkracza w obszar nienormatywnych tożsamości seksualnych i genderowych, kiedy jedną z par przebywających w mieszkaniu treningowym tworzą dwie aktorki. Teatr 21 zwraca zatem uwagę na zagadnienie $\mathrm{w}$ gruncie rzeczy pomijane $\mathrm{w}$ dyskusjach na temat seksualności osób z niepełnosprawnością intelektualną, które w większości ograniczają się do kwestii relacji heteronormatywnych ${ }^{42}$. W gruncie rzeczy wszystkie wcześniej wymienione teksty kultury tematyzują przede wszystkim doświadczane przez osoby z niepełnosprawnością intelektualną pragnienie „normalności” - realizacji tradycyjnych modeli rodzinnych i seksualnych, do których odmawia się im dostępu. W dużo mniejszym stopniu odnoszą się do tego, co Tobin Siebers nazywa „kulturą seksualną", obejmującą wielce zróżnicowane i różnorodne doświadczenia seksualne

40 J. Rancière Dzielenie postrzegalnego, s. 70.

41 J. Franczak /acques Rancière: historia literatury i polityka, "Teksty Drugie” 2012 nr 3, s. 189.

42 W kwestii destygmatyzacji heteronormatywnych związków osób z niepełnosprawnością intelektualną warto zwrócić uwagę na książkę socjolożki Doroty Krzemińskiej pt. Być parq z niepełnosprawnościq intelektualnq̨. Studium mikroetnograficzne w kontekście teorii postkolonialnej Homiego K. Bhabhy (Oficyna Wydawnicza Impuls, Kraków 2019), której zapowiedzi ukazały się w czasie powstawania niniejszego artykułu. 
osób z niepełnosprawnościami, które niekoniecznie muszą wpisywać się w normatywne modele sprawnej seksualności ${ }^{43}$. To dyssensualny obszar doświadczeń, który nadal w znacznej mierze pozostaje w sferze tabu.

\section{Abstract}

\section{Katarzyna Ojrzyńska}

UNIVERSITYOF ŁÓDŹ

My Business: Marriage and Sexual Rights of People With an Intellectual Disability on the Stage and Screen

Taking Len Collin's film Sanctuary and its impact on Irish society as a starting point, Ojrzyńska examines how various contemporary Polish cultural texts (the soap opera Klan [Clan], the performance Moja sprawa [My Business] by the theatre BRO, and Klauni [Clowns] by Teatr 21) address marriage and sexual rights of people with an intellectual disability. Using Jacques Rancière's concepts of representational and aesthetic regimes of the arts and the tenets of contemporary critical disability studies, Ojrzyńska demonstrates that these works serve as a form of protest against the ableist status quo. The article examines the significance and effectiveness of such forms of protest and empowerment through art devised by people with an intellectual disability.

\section{Keywords}

cultural studies on disability, intellectual disability, series, theatre, film, sexuality, Jacques Rancière

43 T. Siebers Disability theory, University of Michigan Press, Ann Arbor 2008, s. 148-149. O nienormatywnych formach seksualności osób niepełnosprawnych (w tym również osób z niepełnosprawnością intelektualną) piszą Paulina Szkudlarek i Sławomira Raczyńska (Zboczone kaleki. Poza sanonormatywnościq̨ i somatoestetykq). 